Portland State University

PDXScholar

6-16-2021

\title{
Childhood Sexual Abuse in Contemporary Fiction
}

Alana Baldwin-Joiner

Portland State University

Follow this and additional works at: https://pdxscholar.library.pdx.edu/honorstheses

Part of the English Language and Literature Commons Let us know how access to this document benefits you.

\section{Recommended Citation}

Baldwin-Joiner, Alana, "Childhood Sexual Abuse in Contemporary Fiction" (2021). University Honors Theses. Paper 1053.

https://doi.org/10.15760/honors.1079

This Thesis is brought to you for free and open access. It has been accepted for inclusion in University Honors Theses by an authorized administrator of PDXScholar. Please contact us if we can make this document more accessible: pdxscholar@pdx.edu. 


\title{
Childhood Sexual Abuse in Contemporary Fiction
}

\section{By}

Alana Baldwin-Joiner

An undergraduate honors thesis submitted in partial fulfillment of the

\author{
requirements for the degree of \\ Bachelor of Arts
}

In

University Honors

English

Thesis Advisor

Bill Knight

Portland State University 


\section{Introduction}

This project will analyze and consider the ways that childhood sexual abuse is portrayed in contemporary fiction by focusing on the fictional representation of these cycles of violence through the lens of literary justice. I will consider the power, efficacy, and limitations of such depictions as well as the literary form of justice that takes place for each survivor. For the purpose of this paper, I will be analyzing The Color Purple by Alice Walker, The Perks of Being a Wallflower by Stephen Chbosky, Swagger by Carl Deuker, and The Pact by Jodi Picoult. My central question for this research is: How is the representation of childhood sexual abuse and the subsequent justice depicted, and more specifically, how is a literary form of justice reached in each novel? I argue that these novels use literary justice to show the unique ways in which justice can be found or created, often outside of the legal means that are not available to all survivors. This justice occurs after a psychological perspective and environmental shift for the survivor and sometimes their loved ones, rather than revenge or retaliation enacted upon the abuser. This fictional occurrence represents healing for the survivors in these stories, and thus a form of justice. I argue that these shifts cause a break from the cycles of violence in the characters' lives as a plot device that the authors of these works use to create a form of justice.

\section{Background}

According to the United States Department of Health and Human Services, childhood sexual abuse (CSA) is very common. 1 in 5 girls and 1 in 20 boys are sexually abused as children (National Center for Victims of Crime). Additionally, 1 in 6 women have been raped in their lifetime, and 1 in 33 men (RAINN). The more chilling reality is that the reported statistics are only a piece of the picture, as "The real prevalence of child sexual abuse is not known because so many victims do not disclose or report their abuse. Researchers have suggested rates varying 
from 1\% to 35\%" (Children's Assessment Center). In the United States, about 500,000 children will be born this year who will be sexually abused in their childhood. Children who survive CSA are more likely to experience drug abuse (by 4 times the general population), are more likely to develop PTSD (also by 4 times), and are "3 times more likely to experience a major depressive episode as adults" (RAINN). They are also more likely to be perpetrators of abuse themselves along with the increase in likelihood for alcohol addiction, depression, anxiety, domestic violence survival, and more if their trauma is unresolved and unhealed, creating a cycle of violence that impacts the CSA survivor's life and those around them (RAINN). Both the overwhelming significance of CSA in society and the need for addressing trauma is the basis for this project, with a focus on the ways in which CSA permeates culture through contemporary fiction. "Cycle of violence" is a term that will be especially relevant in my project, as this is the result of the CSA trauma that the survivors break free from through the two shifts in their perspective and in their environment, and that breaking free is what eventually leads them to justice and a healing of their trauma.

\section{Why Fiction?}

Childhood sexual abuse is a widespread issue that impacts far more people than is generally expected. Additionally, CSA goes beyond the actual event in terms of the risks that survivors face post-victimization and the perpetuation of the cycle of violence that results from the abuse. While depictions of CSA in contemporary fiction are rare, such depictions are important for the representation of readers who have experienced such violence themselves and for the opportunity those depictions pose to educate readers on how cycles of violence can be recognized and prevented. Fiction itself is an important space for readers to explore topics that are close to them or with which they are entirely unfamiliar. While the idea of a "safe space" 
created by fiction can be a problematic metaphor in terms of the reader, for the purpose of this paper we can consider fiction to be a sort of "space" for violence to be explored; fiction works as an interesting inbetween space for real life (through realistic experiences like CSA) and make believe (because the particular cases of CSA that fiction discusses did not actually occur, unlike memoir renditions). This is important because this "inbetween" creates a space where readers can learn more about CSA, cycles of violence, justice, and the experiences that those around them or they themselves are experiencing without leaving the safety of non-reality. The importance for readers lies in fiction's potential to act as a place for education without traumatization. Taking this a step further, fiction is where readers can imagine the long term effects of CSA as hypothetical situations, even to the extent of intergenerational trauma. While reading about violence in any form can be traumatizing for readers, the relative "safety" of fiction lies in its lack of reality; the way that readers can escape or where reality can be temporarily forgotten.

Nonfiction and memoir writing can outright tell readers what events, actions, and circumstances led to violence. Fiction can offer memoir-like testimony about CSA and cycles of abuse, but it can also depict these events through multiple perspectives and voices and through the interactions of characters. By changing the narrative voice around trauma, fiction has the potential to help readers recognize cycles of violence in their lives through imagination and self-realization rather than a more direct "telling." Readers are then able to experience the justice that the survivor enacts or experiences, providing an inside perspective or catharsis for the reader on the healing — or lack of healing - from trauma that is so essential for the survivors of CSA.

Fiction is a complicated space for trauma to be explored. In a sense, fiction is a space where readers can escape from reality, but in another, fiction is where violence can be explored 
and learned about from a meditated space that still conveys the intensity and significance of such an event. In my project I am aiming not to ask that fiction reflect the reality of violence and CSA, but to analyze how that violence is discussed through the lens of cycles of violence and the obtaining of some form of justice. Showing where these cycles of violence occur helps readers to recognize these cycles not only in fiction, but in their reality as well. In this way, I am hoping to provide a greater context and significance to my research beyond literary analysis. Focusing on how CSA and the resulting violence and healing are represented in fiction helps us to understand the nature and effects of such traumas. CSA is a complex but incredibly relevant topic, and its representation in literature is widely unexplored. Fiction is, in these ways, a unique place in which to discuss how CSA's cycles of violence are depicted. In this project I will analyze fiction's strategies and techniques for depicting the cycles of violence surrounding CSA, and how these cycles are broken. These cycles are among the most powerful and important parts of testimony about childhood sexual abuse due to their lasting impact on survivors (indicating the control that unhealed trauma can have on a person's life), and may be the most impactful for readers of CSA fiction. Because of this significance, imaging ways out of these cycles of violence is important for readers of fiction that depicts CSA, and one of the ways to break free from these cycles of violence is to find a form of justice. In the works that I will analyze below, this breaking comes from a literary plot device used by all four authors: a shift in characters' perspectives and in their environments.

\section{The Color Purple}

The Color Purple by Alice Walker was first published in 1982, and Walker was the first Black woman to win the Pulitzer Prize the next year. With both movie and Broadway adaptations, this novel "movingly depicts the growing up and self-realization of Celie, who 
overcomes oppression and abuse to find fulfillment and independence" (Foca). Throughout the novel, the protagonist Celie overcomes the intergenerational cycles of violence that she is born into and achieves her own form of justice (in a literary sense) for the abuses she survived following a psychological and environmental shift in her perspective and situation.

Set in the early 1900s, The Color Purple depicts two tales told through letters; one of Celie writing to God and later to her sister, and the other of her sister Nettie writing to Celie while traveling with missionaries. Celie, after a childhood of sexual, emotional, and physical abuse from the man she thinks is her father (Alphonso, who later turns out to be her stepfather), is forced to marry a man who doesn't want her, referred to only as "Mister." After years of being physically, emotionally, and sexually abused by Mister, he brings home the woman he loves (Shug Avery), and Celie begins to love and take care of her. After years of this arrangement, Celie begins a sexual relationship with Shug Avery, leaves her husband, and starts a sewing business in another state with Shug Avery's help. Celie later discovers all of the letters from her sister that her former husband had hidden from her, which tell Nettie's story: she left with missionaries Samuel and Corrine, who unknowingly adopted Adam and Olivia, Celie's children (that she had after her stepfather raped her when she was a child). Nettie goes to Africa with them, and realizes that the children are Celie's. She also finds out that Alphonso is their stepfather, who married their mother to exploit her wealth and fragile mental state after their actual father was lynched for having a successful store. When Corrine dies, Nettie falls in love with Samuel. Celie moved back to her childhood home after Alphonso's death, having legally inherited the house from her birth father. Celie speaks to Mister again, now calling him Albert, whose life has been in steady decline since Celie left and cursed him, and they become friends. When he proposes that they renew their marriage, Celie declines, still loving Shug Avery. After 
leaving a string of lovers, Shug Avery returns to Celie's house, and finally Nettie comes home as well, and the novel ends with them all introducing each other to their families.

Walker depicts CSA through the lens of a child by using very literal language in terms of body parts. This also reflects the time period of the story and the education level of the protagonist, revealing the limitations of Celie's language and vocabulary for abuse and trauma. The result of this is an immediate immersion for the reader into the violent acts taking place in Celie's childhood home. It begins on page one, when Alphonso assaults Celie for the first time. Right away, cycles of violence are evident in Celie's life. Alphonso's abuse throughout her childhood leads Alphonso to attempt to marry Celie off, both because she prevents him from raping her sister as well as her, and because Alphonso declares her "not fresh" and "spoiled" due to the two times she gave birth to his children (Walker, 7). This feeling is addressed further later on, but it begins a cycle that many survivors of CSA feel-the contamination, dirtiness, or "spoiled" for future lovers idea that is ingrained through patriarchal standards of women's virginity and "purity" (Kerstin Jung, Regina Steil). Essentially, misogynistic societal standards tell survivors that their bodies are dirty and no longer worthy of love because of the abuse they've suffered. This is an idea that will also come up in my analysis of The Pact, as it's a common element of CSA survivor stories, and a significant part of the cycles of violence that many survivors experience. This feeling is something that Celie later overcomes, but Alphonso is laying the groundwork for it here. This is additionally connected to the idea that survivors are unworthy of legal help, belief in their stories, or validation in their trauma that occurs in reality and later in Celie's story (Emily Denne, et al). Alphonso attempts to teach Celie that, because he views her as "dirty" and "used," she is not worthy of the same level of respect and belief that other people are. Alphonso warns her future husband that "she tell lies" to ward off any of 
Celie's potential accusations of abuse (Walker, 8). In this way, he is ensuring that Celie goes forward believing that no one will listen to her story, and she will be unable to achieve justice. Because of Alphonso's view that Celie lacks sexual attraction now that he's raped her (as she is less child-like in his eyes now that she's been taken advantage of sexually), Celie is rushed into the marriage with "Mister." In this marriage, more physical, emotional, and sexual abuse occurs, creating even more trauma from which Celie must recover. Even so, after the justice that Walker creates for Celie along her literary journey, the end of the novel shows a happy family, where forgiveness and love are prevalent, and the cycles are broken.

But before that happy place can be reached, Walker creates two shifts for Celie that lead to her breaking from these cycles of violence and achieving justice: a shift in her perspective, and a shift in her environment. Celie's change in perspective begins when her perspective on her abusive marriage changes; she breaks free from the duress and influence of Mister, and decides that she is leaving him. Celie takes revenge on her abuser, Mister, by taking her power back from him as she declares that she is moving to Tennessee with Shug Avery. She tells him, "You a lowdown $\operatorname{dog}$... It's time to leave you and enter into the Creation. And your dead body is just the welcome mat I need" (Walker, 202). Declaring that Mister is not the authority figure that holds power over her allows Celie's perspective on her abuser to shift. She no longer views his abuse as something she must endure, a simple part of life, and therefore realizes that she can have a life that is just and happy. These were also the first words Celie speaks to stand up for herself to her abusers, to the shock of her companions. However, at this point in the story, Celie had discovered that Mister had been hiding her sister's letters from her, leading her to believe that Nettie had died. Furious, Celie declares that "You took my sister Nettie away from me... And she was the only person who love me in the world" concluding with "Nettie and my children coming home 
soon... And when she do, all us together gon whup your ass" (Walker, 202). In this speech, Celie is taking back the power from her abuser and asserting her own power over him in turn. Celie never saw violent retribution or self defense as an option for herself before this moment, contributing to the idea that other people had abilities and rights that she didn't. All of the men in Celie's life abused the women around them, so she believed it was a natural part of life until she saw Mister's son's wife fight back against his abuse, and Shug Avery decide to leave Mister. These two perspective differences led Celie to the realization that there are other options for her: fighting back, and leaving the abusive environment. She decides to do both (Walker, 201). In this moment, Celie is realizing that she is in fact worthy of justice on her own terms, and furthermore, that she has a family of people who love her and will stand with her. She then defends herself physically against Mister, when, after announcing that Mister “ain't dead horse's shit," she counters his attempt to slap her by stabbing her "case knife in his hand" (Walker, 203). This act of justified violence is so far beyond Celie's usual actions and perspective that her companions are left floored, but this is another instance of Walker showing how Celie is changing her mindset and her surroundings in order to break free from the cycles of violence she has grown up in. In a final move before leaving her home, Celie lays a curse on Mister, saying "Until you do right by me, everything you touch will crumble... Everything you even dream about will fail... Every lick you hit me you will suffer twice... The jail you plan for me is the one in which you will rot" (Walker, 209). With this move, Celie feels a spiritual force helping her to take revenge on her abuser, acting for her to right the wrongs of her life. Celie thinks that the words of her curse "come to me from the trees... when I open my mouth the air rush in and shape words" (Walker, 209). In this scene, Celie thinks that nature is quite literally rectifying the wrongs done to her as it acts as the divine force she has been praying to and waiting for 
throughout the novel. While the curse comes from Celie, the power comes from around her. Having the community that she has created for herself, with her friendships and love, Celie feels more empowered than ever before. In this way, Walker links survivors and their surroundings, showing how the people around a survivor can be a force for justice. Furthermore, Walker uses this scene to show how Celie's perspective on being worthy and deserving of justice has changed, where she now thinks such justice is the natural force of the world, rather than something out of reach or impossible for her. Walker is also showing Celie's environment figuratively change before she moves to Tennessee where it literally changes; the nature around Celie is now fighting for her, rather than being a passive agent to the abuse that Celie is surviving. Celie then declares "I'm pore, I'm black, I may be ugly and can't cook... But I'm here" (Walker, 210). This is her final statement of selfhood, as she casts off the dehumanization and gaslighting of her past and steps into a place of empowerment. In this scene, Celie is shedding that contaminated feeling, the feeling that she deserved less than others because of what she had survived, and stepping forward into her power, acknowledging herself and her personhood in the moment. This is a perspective change for Celie, who had previously been as discreet and passive as possible in order to avoid abuse from the men in her life. Acknowledging that she is present, taking up space, and is worthy of being heard, seen, and loved is a change for Celie that helps her break free from the cycles of violence in her life and get justice.

Celie's perspective on her abuser changes after her environment changes as well. After moving away, Celie is able to forgive Mister, now called Albert: "After all the evil he done I know you wonder why I don't hate him" citing his new ability to actually listen to her, the way he also loved Shug Avery like she did, and how he was trying to better his life and make positive changes as the reasons for her new friendship with him (Walker, 264). This moment of 
reconciliation for Celie, when she recognizes that she does not hold any animosity for Albert, is one of the first instances of forgiveness in Celie's journey to heal from her trauma. This perspective shift is where Walker shows readers that Celie has found justice by freeing herself from the control Albert had over her, both literally in their marriage and emotionally in terms of the previously unhealed trauma Celie had survived. It could be argued that Celie is able to reach this place of forgiveness because of the justice that she found for herself by leaving Mister and achieving her own independence in Tennessee through her sewing business, a shift in her environment. In this context, I argue that the literary form of justice Walker is depicting relates to the love that Celie surrounds herself with, the creation of a new, more positive environment for herself that serves to rectify, as much as possible, the childhood that Celie was robbed of. Celie writes, "I am so happy. I got love, I got work, I got money, friends, and time" (Walker, 218). All of these aspects of life were new to Celie after a childhood of abuse, loveless relationships, and no independence. Finding love and sexual desire in her relationship with Shug Avery, a reclaiming of her sexuality for Celie, and creating clothing for women that focuses on personal style and utility rather than the wants of men (moving away from the male-centric world she grew up in), all contribute to Celie's newfound independence and happiness. By achieving happiness and independence for herself, Celie is moving out of the cycles of violence that stem from and cause CSA, changing her mental perspective and her physical environment to break free from her past, heal her trauma, and find justice for herself.

Subsequently to achieving this independence for herself, Celie also inherits her childhood home. Because Celie was unable to obtain justice for the abuse her stepfather inflicted upon her in her childhood, Celie initially refuses the house, telling Alphonso's widow that "anything coming from him, [she] don't want it" (Walker, 249). However, Shug Avery talks her into taking 
the house, and they accomplish their own form of justice by smoking cedar incense and "chasing out all the evil and making a place for good" (Walker, 250). Walker uses this part of the story to show another mixing of the shift in perspective and environment that acts as a catalyst for justice in Celie's journey. The saging is a practice that physically cleanses the space of bad energy for Celie, and the practice of expunging the past from the house allows Celie to mentally reclaim her childhood home and fill it with positive memories, rewriting traumatic ones. Walker uses these two shifts as a plot device that allows Celie to find justice for the childhood abuse she survived. In this context, I would argue that Walker is creating a sense of spiritual justice for Celie; the justice that Celie feels is internal, rather than a physical punishment for her abusers such as legal retaliation. This spiritual and internalized justice is especially significant in Walker's novel because of the racism and misogyny that makes traditional justice nearly unattainable for Celie in the society she lives in. The house itself is a source of complication for Celie, but is also greatly significant for her journey toward justice and recovery from her childhood and early life of trauma. Being able to reclaim this space for herself and to fill it with the people she loves and the people who love her turns the house from a source of fear and trauma to one of happiness and comfort for Celie. Through this conclusion, Celie is able to heal from her past trauma, and move on from the hurt that Alphonso and Albert inflicted on her. After the many years of pain that Celie survived, she is able to heal from her trauma and conclude her story in a place filled with family and happiness, breaking the cycle of violence.

Walker creates a literary justice for Celie not through the traditional means of legal retaliation or revenge, but through a shifting in Celie's perspective and in her environment. When Celie breaks free from the dehumanization and abuse in her marriage, she reclaims her power and personhood for the first time, and recognizes that she deserves more in life. Subsequently, 
she changes her environment by first moving away and creating a business and family that benefits herself and those she loves, rather than the misogynistic and abusive society and situation she grew up in. Later, she returns to her childhood home and reclaims that space as well, spiritually and physically taking it back and recreating memories that are positive, rather than traumatic. Through the two shifts that occur in Celie's story, Walker creates a literary justice for her character, breaking Celie free from the cycles of violence in her life and concluding her story in a positive, loving space filled with justice.

\section{The Perks of Being a Wallflower}

Stephen Chobosky's bestselling, somewhat autobiographical novel The Perks of Being a Wallflower had mixed reception on its publication in 1999, but was overall beloved and was even adapted into a motion picture. This book fits into the discourse community on CSA in fiction by depicting three different characters who are survivors, and who experience cycles of abuse in different ways. Chobosky, like Walker, uses two significant shifts in his characters' journeys to create justice for them: a perspective or psychological shift, and a physical or environmental one. This happens for two survivors in Chobosky's story, unlike Walker's: Charlie and Sam are both CSA survivors who break free from their cycles of violence due to the plot devices Chobosky uses as catalysts, and both achieve a form of literary justice by the end of the novel.

The Perks of Being a Wallflower follows protagonist Charlie, a "wallflower," through the first year of high school, where Charlie befriends two siblings (seniors Patrick and Sam). Charlie was a survivor of CSA in his childhood, although that aspect of his story is merely hinted at until the climax of the story. Charlie falls in love with Sam, who is revealed to also be a CSA survivor. Throughout the story, Charlie has flashbacks of his aunt Helen, who died in a car accident while

driving to get him a birthday present. When, near the end of the novel, Charlie finally acts on his 
feelings for Sam, the repressed memories of the childhood sexual abuse by Helen resurface, Charlie goes into a catatonic state, and is hospitalized for two months. When he is released, he decides to "participate in life" and stops writing letters, the form through which his story was being told. This final act is used as both a way to conclude the story and a way to signify the break from Charlie's cycle of violence and acquisition of justice.

CSA makes three appearances in this story: through Charlie's best friend, Sam, through his aunt Helen, and through Charlie himself. For Sam, the abuse she survived impacts her relationships throughout her teenage years (the only time we as readers are privy to). For Helen, a string of abusive relationships, money problems, and the abuse of Charlie follow in her cycle of violence. And finally, Charlie represses the memories of his abuse until an intimate moment with Sam, where he has a breakdown and is hospitalized. These three cycles of violence intertwine in a way that is vital for the exposure to readers of the impacts of abuse on survivors and the rest of their lives. While the abuse each character survived occurred in childhood, the violence stemming from it continues throughout the story, and for Helen until the day she dies. This helps readers to understand that survival is more than one event, and is a continuous journey to break from the cycle of violence. Finally, the assertion of the term "wallflower" creates a multifaceted image for the reader: we initially believe that Charlie is merely antisocial and shy, but learn later that "wallflower" also covers a deep traumatic past, a trauma that forms a kind of wall between Charlie and his friends that makes him feel that he cannot fully participate in life. This, as mentioned above, creates a recognizable symbol that shows readers when Charlie is trapped in cycles of violence, and when he is free and has justice, and thus is able to heal from his trauma, he no longer identifies with the "wallflower" term. 
The cycles of violence that each CSA survivor in The Perks of Being a Wallflower work through follow statistical norms, something that creates an interesting sense of reality in Chobosky's novel. While this helps readers recognize signs of CSA and cycles of violence in their own lives, I would argue that it also impacts the readers in a way that more distance from the violence they're reading about might not, and draws them away from that space where trauma can be explored with less retraumatization than nonfiction as a genre. This varies from The Color Purple in that that novel was set in a time and environment that many readers cannot fully relate to in today's age; they relate more in events than in literal environment, and the combination of events and environment relation in The Perks of Being a Wallflower creates an interesting experience for the reader. While there is something to be said for distance from a violence being also quite impactful, in this novel, the reader is very close to the feelings and realities of the characters, and the target audience can empathize quite a lot with the circumstances and setting. Furthermore, these cycles of violence set the foundation for the two shifts that Chobosky uses in Charlie and Sam's character journeys in order to create literary justice for them.

Sam has a long term relationship with a man who cheats on her and is generally abusive, and also develops a drug and alcohol dependency throughout the novel. Charlie also experiences drug and alcohol dependency, post traumatic stress disorder, struggles with his mental health, has relationship issues, and discovers an inability to be intimate with the woman he loves due to the cycle of violence that began with the abuse he survives. These cycles of violence are intertwined in that the abuse Helen survived leads to her abusing Charlie, who in turn finds comfort with Sam but cannot move forward in their relationship. Sam's story happens alongside Charlie's and in a way gives reason to Charlie's journey — we as readers are unaware that Charlie was abused 
until the end of the novel, but we understand Sam's story, so we can apply that reasoning to Charlie's in retrospect. In a way, Sam is living a very similar story to Charlie, just in a more visible context to the reader. Chobosky shows that trauma can appear in many forms, and gives validation and shines a light on this truth. Furthermore, the impact of Charlie's full story being revealed near the end of the novel causes the reader to go back and reflect on the previous pages, where signs of Charlie's trauma survival are hinted at subtly. This is powerful in a literary sense, and also indicates to readers where they might see cycles of violence and evidence of abuse in their own lives.

Chobosky's two shifts in perspective and environment happen for Charlie and Sam at different times. Charlie's perspective on his past changes when he is able to remember the abuse he survived, which helps him feel validated for struggles he experienced during his cycle of violence that he did not fully understand previously (Chobosky, 208). His environment changes temporarily when he is hospitalized, but this is when he is able to receive the help he didn't know he needed throughout his story, saying "the doctor helped me work out a lot of things since then. About my aunt Helen. And about my family. And friends. And me. There are a lot of stages to these kinds of things, and she was really great through all of them" (Chobosky, 209). While Helen's death means that Charlie did not get a chance for legal justice, after these two shifts he is able to overcome the repressed memories and seek help, leading to a break in the cycle of violence for him and thus a form of literary justice. After he feels a sense of justice and healing, Charlie writes that he is going to start to "participate" in life, and take a more active role in the things that are happening around him - in other words, no longer be a wallflower (Chobosky, 213). This is a huge growth for Charlie, and shows that the cycle of violence he was trapped in has been escaped from, and the trauma has been healed. Because the story is told from Charlie's 
point of view, we see Sam's perspective and environmental changes when she verbalizes them to Charlie, rather than following that aspect of her journey. Sam has a shift in perspective when she realizes that, while she cannot change her own past, she can change the story for those around her, and thus become an active force for justice rather than a passive survivor of past violence. When she tells Charlie about the abuse she survived, she tries to make sure that his experiences have more justice and a different perspective than hers, saying "I want to make sure that the first person you kiss loves you" (Chobosky, 70). Sam feels robbed of her first kiss, a memory that cannot be replaced. She thinks that if she can make sure that Charlie's first kiss memory is a good one that she will somehow negate some of the harm that might come to him later. This is a different perspective than Sam had before, when she viewed the violent nature of life as inevitable and unfightable (Chobosky, 69). After this realization and change for Sam, she goes on to create more change for herself, deciding to change her environment as well. Sam declares that, when she leaves for college, she will break free from the patterns she was trapped in. She tells Charlie, "I'm not going to let that happen again with anyone else. I'm going to do what I want to do. I'm going to be who I really am. And I'm going to figure out what that is" (Chobosky, 202). While Sam also doesn't get legal justice from her abuser, she does break free from the cycle of violence by creating for herself a fresh start, a kind of justice in being able to change the patterns that hurt her in the past. We as readers don't see the result of this environment change, although the hope for the future and psychological change in Sam after the decision to shift her environment symbolizes the same breaking from cycles of violence and healing of trauma as Charlie's.

Chobosky manages to create unique perspective and environmental shifts for both of his living CSA surviving characters, leading to them getting justice and healing from their traumas. 
Overall, the novel provides an example of unconventional recovery for those to whom legal justice is unavailable. For survivors who cannot get justice by confronting their abusers, for those whose cycles of violence look like drug and alcohol abuse and mental health challenges, and for survivors who cannot fully remember the trauma of their past, Chobosky shows where justice can be found after a shift in perspective and situation, and leaves readers with the feeling that, even after all of the violence and trauma, healing can be found.

\section{Swagger}

Swagger was published in 2013 by Carl Deuker, a former teacher who writes fictional books about sports that tackle difficult situations like steroids and sexual abuse. While Swagger isn't his most famous novel, he has had some award winning titles, and now writes full time. Despite its lukewarm popularity, Swagger has ignited conversations in school systems and athletics around sexual abuse. Throughout Swagger, readers are able to explore abuse and trauma from an outside point of view, rather than that of the survivor themself. This is powerful because it allows readers to imagine what it would look like if they were in the position to support survivors in their own lives, and what a CSA situation could look like. This also creates an interesting difference for the environmental and perspective shifts that occur in Deuker's plot in order for justice to be found for the characters, as the other works so far in this project have been more direct in their telling. Additionally, Deuker relies on the sense of justice derived from more traditional means, where the survivor (or someone in the know) reports the abuse to authorities. In a great twist that shows more of the reality of our society, Deuker also challenges this narrative by having that legal form of justice not be entirely satisfactory.

Swagger by Carl Deuker depicts high schooler Jonas Dolan's story as he moves to a new school, fights to earn a spot on the starting basketball team, and earns a scholarship to college, 
which he has to improve his playing and grades to do. Meanwhile, Jonas' new best friend Levi is secretly being sexually abused by their assistant (and later substitute) basketball coach, Hartwell, who also helps Jonas cheat on chemistry tests. After finding out about the abuse, Jonas wants to tell someone and Levi doesn't. They wait until after the championship game, which Levi is committed to for Jonas' college chances. Levi dies by suicide the night after the game and a grieving Jonas decides to tell the principal about Hartwell, even though he knows Hartwell will subsequently sabotage his basketball scholarship by revealing the cheating.

While Levi doesn't fall into many of the usual cycles of violence that survivors face such as drugs, alcohol, or abusive relationships, he does experience mental health struggles. Jonas says, "The guy with the clenched fists and the eyes filled with hatred wasn't the Levi I'd known" (Deuker, 174). The gradual change in Levi-becoming more quiet, angry, and less social—follows the norm for a person struggling with depression and abuse (RAINN), but also sets the stage for the perspective change that occurs in Jonas that eventually leads to justice for Levi. After seeing his best friend become unrecognizable through the abuse Hartwell inflicts on him, Jonas is convinced that he must act. This change in mental perspective leads Jonas to pry the truth from Levi, and later to convince him that they have to tell someone with authority (Deuker, 134). Next, Jonas changes his environment by sacrificing his relationship with his basketball teammates and his future college plans when he tells the principal about the abuse, turning in Hartwell. Jonas tells the principal, "He's the reason Levi is dead... He did terrible things. You've got to stop him, or he'll do them to somebody else" (Deuker, 275). This hints at the perspective change in Jonas as well, since the realization that preventing future abuse is more important than temporary retaliation against him for telling is what motivates Jonas to finally seek help. While these changes are not a necessarily positive one for Jonas, it does lead to justice 
for Levi, and subsequently for Jonas as well. However, another set of perspective and environmental change are written for Jonas later in his story: After losing his scholarship, Jonas decides to attend a community college and not let Hartwell's actions derail his life, declaring "Hartwell is not going to steal my life from me... I'm going to do all these things for myself, and I'm going to do them for Levi, too" (Deuker, 297). In this way, Deuker ensures that, while Levi and Jonas' justice is linked, Jonas also has a healed conclusion to his story. The novel ends on that message of hope, and of moving forward. In this way, Deuker shows readers that healing and recovering from a cycle of violence is a process, or as Jonas calls it "a whole bunch of steps to follow" (Deuker, 296). The perspective that healing is a process helps Jonas retain hope that there is always something to be done to move forward or to heal, leading him to break free from the cycles of violence in his life and heal from his trauma.

Swagger is a great example of where fiction can show stories from alternative perspectives than the direct CSA survivor, and how certain scenarios can be tested out in a hypothetical, fictional setting. Readers get to see the signs of abuse and cycles of violence from the perspective of a friend on the outside, helping them possibly recognize those signs in their own lives. Deuker uses the same two shifts in both perspective and environment that the other authors in this project use, but he applies them to both Levi, the actual CSA survivor, and Jonas, his friend and fellow trauma survivor. In this way, both Levi and Jonas are able to find justice, and Jonas is able to break free from the cycles of violence in his life and heal from his trauma.

\section{The Pact}

Jodi Picoult's fifth book, The Pact, was published in 1998, and focuses on love, grief, and abuse. Picoult is an international bestselling author of books that tackle difficult situations, 
contain legal dramas, and involve families being pitted against each other. The Pact was a New York Times Bestseller and was adapted into a film in 2002.

The Pact is a complicated story of two teenagers in the spirals of mental illness and love. After growing up together, Emily and Chris begin dating. Several years into their relationship, Emily finds out that she is pregnant and decides not to tell Chris. She tries to have an abortion, but the male doctor reminds her of the childhood sexual abuse she survived, and she backs out at the last minute. She then decides that death by suicide is her only option, as she doesn't want to have the baby and isn't sure if she wants to spend her life with Chris. She enlists Chris' help, and when she finds she can't pull the trigger herself, they both put their hands on the gun. In the end Chris (who, at the time of the story's full telling, is on trial for murder) isn't sure who actually pulls the trigger, but Emily dies and Chris falls unconscious. What was assumed to be a suicide pact grows complicated with families hiding evidence, turning on each other, and ultimately hashing things out in a court of law where Chris is deemed not guilty.

The childhood sexual abuse that Emily survives is a one time event at a restaurant, but keeping the secret and the subsequent cycle of violence from the event consumes Emily's life. While Emily never tells anyone about the abuse, an art analyst the lawyers bring in to look at Emily's art for the trial discovers several symbols that are markers for childhood abuse, "Victims of abuse fixate on tongues, eyelashes, and wedge-shaped objects. Also belts" (Picoult, 435). Here Picoult uses her storytelling to help readers recognize signs of abuse in their real lives. While Emily's survival isn't a well-known aspect of the story, it does play a significant role in the novel.

The cycle of violence that Emily endures revolves around her mental health and her ability to be intimate with her partner. Emily writes repeatedly in her journal about feeling 
"dirty," and that she is lying to Chris because of her perceived impurity after the abuse she survives (Picoult, 252). Both of these feelings are common experiences for survivors of CSA, and are also explored in The Color Purple. While Picoult uses this element of shame throughout Emily's story to show how CSA looks for many survivors in real life, this emotional conflict also functions as a literary drive that fuels many of Emily's decisions, and ultimately leads to the climax of the novel. In this way, Picoult uses a perspective change in the opposite way of the other works in this project: Emily's perspective changes negatively, and this shift eventually leads to her death. Another aspect of Emily's cycle of violence involves her sexual relations with Chris. Despite a loving relationship and a deep, lifelong trust, Emily finds that she cannot have sex with Chris for the first three years of their relationship, saying she "did not know waht sex was supposed to feel like, but she guessed it wasn't having your skin shrink back from his, your stomach roll, your head pound" (Picoult, 180). A mixture of the tainted feeling that lingers from her abuse, the thought that she is lying to Chris by not telling him about it, and the residual trauma of the CSA she survived keeps Emily from that level of intimacy. When she finally is able to be with Chris in that way, it ends up being a negative experience, something that she endures only for the intimacy of lying together afterwards, "This was the part she waited to get to, the part worth suffering through the sex" (Picoult, 261). Through these experiences, Picoult shows readers how cycles of violence can maintain influence over time, despite Chris' best efforts to make Emily feel loved and safe. These scenes shift the blame from the environment - Chris and the pressure to be intimate with him—-to the abuse, something that Emily hadn't gotten to heal from. That lack of healing impacts Emily later as well, when she tries to get an abortion. The male doctor attempting to administer the abortion triggers a traumatic memory of her CSA in Emily, and she kicks him away and asks the nurse not to let him touch 
her (Picoult, 263). This final straw, being unable to get the abortion she wants due to her trauma, causes Emily's suicidal ideation to increase, as she feels trapped and out of other options. The denial of care that Emily faces due to the cycles of violence resulting from the CSA she survived acts as a catalyst for the fatal events that follow, but also can be used as a way to see where justice should have been accessible or even achieved for Emily, as do the other moments where Picoult shows the readers injustices in Emily's story. In this way, Picoult is showing a shift in Emily's environment in yet another negative twist, rather than the positive ones that lead to healing. Emily's pregnancy and inability to receive the care that she needs changes her environment from bad to worse, and leads to her death by suicide. In this way, Picoult shows how shifts in perspective and environment can be positive or negative, and what can result.

While Emily dies before her perspective or environment can shift in a positive way as a plot device to help her break free from this cycle of violence and thusly heal from her trauma, Picoult uses the same tactic on Chris instead in order to retroactively achieve justice for Emily and subsequently to find justice for Chris (who has also been through a trauma, albeit not CSA). Picoult shifts Chris' literal environment when he is imprisoned, where he meets people and hears stories that change his perspective on life (Picoult, 201). His mental perspective on his relationship also changes when he learns more about Emily during his court trial, where he hears that she was pregnant, was struggling with her mental health, and that she was a survivor of CSA. This helps Chris to heal from the trauma of Emily's death because he discovers that he is not at fault for the way that she felt and the way she eventually died (Picoult, 288). This aids him in breaking free from the cycle of violence his life was intertwined with, and later healing from his trauma. 
Because Emily does not confront her abuser or tell anyone about the abuse, she does not, as a literary character, see justice for the trauma she survived. However, the recognition of her story after her death acts as a kind of justice, a seeing of her for who she was and what she was dealing with that provides a greater context to her family and loved ones. Emily's parents are present in the courtroom when the artistic signs of abuse are revealed to be present in Emily's work, leading to her story being heard by the people closest to her (Picoult, 436). In the end, bearing witness to her survival and the pain it caused her is the only justice available to Emily, and in this way Picoult gives readers as much conclusion to Emily's story as she realistically can. This causes a shift in the perspective of the characters around Emily, in that finally understanding what she was going through gives them a new outlook on her situation and what caused her death.

Throughout The Pact, Emily experiences a cycle of violence stemming from the childhood sexual abuse she survives. She struggles with her mental health, self harm, suicidal ideation, and a difficulty with intimacy. And in the end, she gets a limited form of justice in that her abuse is revealed to her family, and they understand her story better. Picoult uses negative perspective and environment shifts in Emily's story in order to show how this plot device can go wrong in a character's journey, but she also uses these two shifts in Chris' story in order to show where breaking from the cycles of violence, justice, and healing can happen.

\section{Reading These Works Together}

The Color Purple, The Perks of Being a Wallflower, Swagger, and The Pact are all works that depict different time periods or situations, were published at different times, and were written by different authors. However, they all tell important stories about CSA, and offer different perspectives and situations that provide what was discussed in the "Why Fiction" 
section of this project: the opportunity for readers to explore trauma without traumatization, to see different situations and circumstances play out as hypothetical scenarios without literal consequences, and chances for readers to see where cycles of violence might be happening in their own lives, and where justice can be found or created as well.

These works also all share similar plot devices that are used to break the characters free from the cycles of violence in their lives and to give the characters and their loved ones a form of literary justice and a healing from their trauma. By shifting both the perspective and environments of one or more characters, Walker, Chobosky, Deuker, and Picoult all create literary justice for their characters.

\section{Conclusion}

In The Color Purple, The Perks of Being a Wallflower, Swagger, and The Pact, each survivor finds or receives some facet of literary justice, and, subsequently, some resolution to the cycles of violence that stem from the abuse they survived. While justice looks different for every character based on their stories, this justice is found after each novel's author creates a perspective and environmental shift in the plot, resulting in the characters breaking from the cycles of violence they were previously trapped in, finding justice, and healing from their trauma. 


\section{Works Cited}

1. Chbosky, Stephen. The Perks of Being a Wallflower. Thorndike Press, a Part of Gale, Cengage Learning, 2020.

2. Chbosky, Stephen. “The Perks of Being a Wallflower: Paperback.” Barnes \& Noble, MTV Books, 14 Aug. 2012, www.barnesandnoble.com/w/perks-of-being-a-wallflower-stephen-chbosky/1100365675.

3. Denne, Emily. “Assessing Children's Credibility in Courtroom Investigations of Alleged Child Sexual Abuse: Suggestibility, Plausibility, and Consistency.” Sage Journals, 8 Sept. 2019, journals-sagepub-com.proxy.lib.pdx.edu/doi/full/10.1177/1077559519872825.

4. Deuker, Carl. Swagger. Houghton Mifflin Harcourt, 2015.

5. Edemariam, Aida. "Interview: Alice Walker." The Guardian, Guardian News and Media, 23 June 2007.

www.theguardian.com/books/2007/jun/23/featuresreviews.guardianreview23\#: :text=Th e\%20book\%20altered\%20the\%20face,and\%20with\%20her\%20only\%20daughter.

6. Fergusson, David M, et al. "Childhood Sexual Abuse and Adult Developmental Outcomes: Findings from a 30-Year Longitudinal Study in New Zealand.” Child Abuse \& Neglect, vol. 37, no. 9, 2013, pp. 664-674.

7. Hopkins, Ellen. Identical. Simon \& Schuster, 2008.

8. Horvitz, Deborah M. Literary Trauma : Sadism, Memory, and Sexual Violence in American Women's Fiction. State University of New York Press, 2000.

9. Jung, Kerstin, and Regina Steil. "The Feeling of Being Contaminated in Adult Survivors of Childhood Sexual Abuse and Its Treatment Via a Two-Session Program of Cognitive 
Restructuring and Imagery Modification: A Case Study.” Sage Journals, 21 Sept. 2011, journals-sagepub-com.proxy.lib.pdx.edu/doi/full/10.1177/0145445511421436.

10. Noll, Jennie G. "Does Childhood Sexual Abuse Set in Motion a Cycle of Violence Against Women?” Journal of Interpersonal Violence, vol. 20, no. 4, 2005, pp. 455-462.

11. Sharp, Lois Dawn. Medical Treatment and Adult Survivors of Childhood Sexual Abuse, 1997.

12. Walker, Alice. The Color Purple. Weidenfeld \& Nicolson, 2019.

13. Walker, Alice. "The Color Purple by Alice Walker: 9780143135692 :

PenguinRandomHouse.com: Books." PenguinRandomhouse.com, Penguin Adult HC/TR, www.penguinrandomhouse.com/books/639346/the-color-purple-by-alice-walker/.

14. “Children's Book Review: Swagger by Carl Deuker. Houghton Mifflin Harcourt, $\$ 17.99$ (304p) ISBN 978-0-547-97459-0." PublishersWeekly.com, 14 Oct. 2013, www.publishersweekly.com/978-0-547-97459-0.

15. "Children and Teens: Statistics." RAINN, www.rainn.org/statistics/children-and-teens.

16. "Child Sexual Abuse Facts \& Resources." Children's Assessment Center, cachouston.org/sexual-abuse/child-sexual-abuse-facts/.

17. "Child Sexual Abuse Statistics." The National Center for Victims of Crime, victimsofcrime.org/child-sexual-abuse-statistics/.

18. "The Color Purple.” Wikipedia, Wikimedia Foundation, 2 May 2021, en.wikipedia.org/wiki/The_Color_Purple.

19. “The Pact (Novel).” Wikipedia, Wikimedia Foundation, 14 Apr. 2021, en.wikipedia.org/wiki/The_Pact_(novel).

20. “The Pact Study Guide.” GradeSaver, www.gradesaver.com/the-pact. 
21. "The Perks of Being a Wallflower." Wikipedia, Wikimedia Foundation, 11 Apr. 2021, en.wikipedia.org/wiki/The_Perks_of_Being_a_Wallflower.

22. "Victims of Sexual Violence: Statistics." RAINN, www.rainn.org/statistics/victims-sexual-violence. 